DOI: https://doi.org/10.24144/2409-6857.2018.1(51).47-52

УДК 005.21:005

\author{
Кравченко В.O.
}

\title{
КРОС-КУЛЬТУРНИЙ МЕНЕДЖМЕНТ В РЕАЛІЗАЦІЇ СТРАТЕГІЇ РОЗВИТКУ МІЖНАРОДНИХ КОМПАНІЙ
}

\begin{abstract}
Статтю присвячено розгляду питань крос-культурного менеджменту в реалізації стратегії розвитку міжнародних компаній. У процесі дослідження визначено: авторські підходи щзодо змісту сутності поняття «стратегія» та роль крос-культурного менеджменту. Проаналізовано погляди щодо значення крос-культурного менеджменту у створенні конкурентних переваг міжнародних компаній. Визначено вплив крос-культурного менеджменту на підвищення ефективності діяльності та посилення конкурентних переваг підприємства. Доведено вплив розмаїтості на ефективність крос-культурного менеджменту та обтрунтовано, щчо культурну розмаїтість треба використовувати як ресурс переваг міжнародної компанії, навчати персонал визнавати культурні розходження та використовувати їх для створення переваг своєї компанї.
\end{abstract}

Ключові слова: крос-культурний менеджмент, стратегія розвитку міжнародних компаній, розмаїтість, конкурентна перевага, конкурентоспроможність,позитивний імідж.

Постановка проблеми. У сучасних умовах розвитку глобалізації процеси світової інтеграції стали загальноприйнятими, оскільки дедалі більше компаній виходять на міжнародні ринки, започатковують бізнес в інших країнах i створюють альянси з закордонними компаніями. Завдяки експансії на глобальні ринки та в інші країни, транснаціональні корпорації отримують значні конкурентні переваги, зокрема нові ринки 3 великою кількістю потенційних споживачів та можливість наймати працівників, що виконують нескладні роботи з меншою винагородою. Отже недостатнє використання можливостей потенціалу крос-культурної взаємодії може призвести до суттєвого зниження ефективності міжнародного співробітництва. Водночас, аналіз вітчизняних джерел наукових досліджень i практичного досвіду свідчить про те, що проблемі ефективної взаємодії різних культур як важливої складової реалізації стратегії розвитку міжнародних компаній в України не надається достатньої уваги.

Саме тому, в умовах глобалізації бізнесу перед міжнародними компаніями стоїть стратегічна задача - налагодження ефективної співпраці та подолання бар'єру між різними поглядами, культурними упередженнями, які стосуються крос-культурних розбіжностей між партнерами цих компаній.

Аналіз останніх досліджень і публікацій. Перші наукові уявлення про організаційну

(C) Кравченко Віра Олексіӥвна, к.е.н., професор, професор кафедри менеджменту організацій та зовнішньоекономічної діяльності, Одеський національний економічний університет, м. Одеса, тел.: 0503951953, e-mail: nikiforenko@te.net.ua (корпоративну) культуру з'являються у західній літературі на початку 80 -х років XX ст. завдяки дослідженням Т. Дж. Пітерса, Р. Х. Уотермена, $€$. Шейна, К. Камерона та інших учених. Розвиток управлінських наук став поштовхом для виокремлення нового напрямку - ресурсного підходу, у рамках якого підвищення ефективності організації перш за все досягається за рахунок підвищення ефективності іiі персоналу, при цьому в якості методів стимулювання використовується можливість творчої самореалізації, причетності до управління. Тому формування поглядів на організаційну культуру як механізм регуляції трудової поведінки персоналу стало очевидним.

Класичний підхід до розуміння впливу культури на міжнародну економічну діяльність грунтується на понятті культури як емпіричної категорії, що відображає відносно стабільну, однорідну, внутрішньо несуперечливу систему специфічних припущень, цінностей та норм, які можна об'єктивно описувати; щось, чим колективно володіють члени групи, організації або нації, або чим вони користуються. Цей підхід розглядає особливості національних культур та дозволяє зрозуміти, як ці особливості впливають та визначають специфіку ведення бізнесу в тій чи іншій культурній системі.

Культура $є$ фундаментальною та визначальною базою формування будь-якої економічної системи. Один із найбільш впливових представників цього наукового напрямку С. Хантінгтон вважає, що дистанційнування культур є перешкодою на шляху до ефективних міжнародних економічних відносин: «...народи та країни з подібними культурами йдуть разом, народи i країни з різними культурами йдуть порізно» [17]. 
Вивченню особливостей застосування кроскультурного аналізу управління міжнародними компаніями присвячені роботи закордонних та українських вчених, зокрема: К. Бартлетта, Дж. Блека, М. Борга, В. Годвінга, С. Госхела, Х. Грегерсена, М. Менденхелла, Г. Хедлунга, А. Белорусова, О. Кириченкоа, С. Мясоєдова. Розвиток наукових підходів щодо дослідження категорії крос-культурного менеджменту в процесі стратегічного управління знайшов відбиття у працях зарубіжних та вітчизняних науковців, а саме: К. Камерона, Т. Пітерса, Р. Уотермена, Е. Т. Холла, Р. Д. Левіса, Г. Хофстеде. Серед українських науковців це: О. Буряк, Н. Мешко, C. Пайванд, Р. Папка, Ю. Петрушенко, Н. Попова, О. Рогач, О. Романуха, Н. Тодорова, В. Шинкаренко, В. Щетініна, та інші. У той же час, аналіз досліджень і публікацій свідчить, 3 одного боку, про наявність великої кількості поглядів щодо указаної проблеми, а з іншого боку про те, що у багатьох випадках науковці досліджують ті аспекти, у яких вони є визнаними фахівцями (психологічні, управлінські та т.і.).

Виділення невирішених раніше частин загальної проблеми. За оцінками фахівців в умовах глобалізації бізнесу та реалізації стратегії розвитку перед міжнародними компаніями постає завдання подолання крос-культурних розбіжностей. Очевидно, що наявність різних думок науковців свідчить не тільки про розмаїття думок, але й про наявність певних прогалин у реалізації складної і багатопланової системи крос-культурного менеджменту в стратегії управління міжнародних компаній.

Формування цілей статті. Особливого значення для розвитку міжнародної компанії набуває стратегія, яка повинна гармонізувати вплив i взаємозв'язки між чинниками внутрішнього та зовнішнього середовища. Отже, постає завдання визначення переваг кроскультурного менеджменту в процесі реалізації стратегії розвитку. Саме таку мету визначив автор даного дослідження - дослідження підходів щодо трактування крос-культурного менеджменту в системі стратегічного управління міжнародних компаній. Для досягнення визначеної мети були виокремленні відповідні завдання, а саме: вивчення та узагальнення думок учених щодо сутності крос-культурного менеджменту та стратегічного управління; визначення авторського бачення ролі i взаємозв'язків крос-культурного менеджменту в системі стратегічного управління міжнародних компаній; формування відповідних висновків i пропозицій.
Опис основного матеріалу дослідження. Виходячи 3 теми дослідження, розкриємо сутність стратегії розвитку підприємства та обгрунтуємо значущість крос-культурного менеджменту. Відносно змісту та різновидів стратегій організації в літературі зі стратегічного менеджменту існують різні погляди. Різноманітність поглядів на сутність поняття «стратегія» наведено у таблиці.

Отже, стратегічне управління забезпечує утримання конкурентних переваг та урахування в практичній діяльності крос-культурної діяльності специфіки ведення міжнародного бізнесу.

Чим більш відкритими для світу стають бізнес-кордони країни, тим більше у ній 3'являються міжнародні компанії, які стикаються 3 проблемами крос-культурної взаємодії в процесі реалізації стратегії розвитку. Виокремлення поняття крос-культурного менеджменту відбулося ще у середині XX століття. Вивчивши досвід 62 провідних високотехнологічних американських компаній, Т. Питерс, Р. Уотерман зробили висновок, що більшість 3 них утримують відповідні структурні підрозділи і запроваджують спеціальні програми, спрямовані на діагностику i вдосконалення культури, відносини між керівництвом i працівниками будуються за принципом «продуктивність - від людини» [11, с. 297].

Необхідно зазначити, що українські науковці приділяють проблемам крос-культурного менеджменту значний інтерес, про що свідчать відповідні публікації в фахових виданнях.

Як зазначає Ю. Петрушенко, основною метою крос-культурного менеджменту $\epsilon$ сприяння узгодженню дій в роботі та навчанні під час контактів, у яких культури як історично сформовані знання, цінності та досвід включаються у спільну мультикультурну діяльність. Крос-культурна трансляція знань сприяє створенню нового унікального знання, тобто такого, яке навряд чи може виникнути в штаб-квартирі корпорації [12].

Н. Мешко зазначає, що для того, аби бути у змозі вижити в глобальному конкурентному середовищі, ресурси повинні бути використані якомога ефективніше, а також гнучко, i це значною мірою стосується персоналу компанії $[8$, c.156].

Згодом, зазначає О. Буряк, почали досліджувати питання крос-культурного менеджменту та впливу національних культур та мовних відмінностей на управління персоналом $[3$, c. 121$]$. 
Авторські підходи щодо визначення сутності поняття «стратегія»*

Таблиця 1

\begin{tabular}{|c|c|}
\hline Автор & Визначення поняття \\
\hline \multicolumn{2}{|r|}{ Стратегія як модель (план дій) } \\
\hline $\begin{array}{l}\text { Азоєв } Г . \\
{[1, \text { с. } 56]}\end{array}$ & $\begin{array}{l}\text { «Стратегія - це план дій організації, спрямований на досягнення успіху у конкурентній } \\
\text { боротьбі на певному ринку» }\end{array}$ \\
\hline $\begin{array}{l}\text { Карлофф Б. } \\
{[7, \text { с. } 148]}\end{array}$ & $\begin{array}{l}\text { «Стратегія - це узагальнена модель дій, необхідна для досягнення поставлених цілей } \\
\text { шляхом координації та розподілу ресурсів компанії» }\end{array}$ \\
\hline $\begin{array}{l}\text { Іванов Ю. } \\
{[6, \text { с. } 70] .}\end{array}$ & $\begin{array}{l}\text { «Стратегія - це ретельно розроблена програма заходів, яка має бути реалізована } \\
\text { організацією, з метою досягнення вигідної конкурентної позиції на ринку та адаптації } \\
\text { підприємства до змін у внутрішньому та зовнішньому середовищі» }\end{array}$ \\
\hline Р.Папка [10] & $\begin{array}{l}\text { «Стратегія розвитку міжнародної компанії може бути визначена як довгостроковий } \\
\text { план напрямку розвитку та створення внутрішніх та зовнішніх умов для успішного } \\
\text { розвитку» }\end{array}$ \\
\hline \multicolumn{2}{|r|}{ Стратегія як напрямок руху } \\
\hline $\begin{array}{l}\text { Чандлер А. Д. } \\
{[16, \text { с. } 18] .}\end{array}$ & $\begin{array}{l}\text { «Стратегія - це визначення основних довгострокових цілей підприємства, адаптація } \\
\text { курсів дій та розміщення ресурсів, необхідних для досягнення цілей» }\end{array}$ \\
\hline $\begin{array}{l}\text { Балабанова Л .В. } \\
{[2, \text { с.32,36,] }}\end{array}$ & $\begin{array}{l}\text { «Стратегія - це концепція та підпорядкована їй система дій підприємства, направлених } \\
\text { на досягнення його кінцевих цілей» }\end{array}$ \\
\hline \multicolumn{2}{|r|}{ Стратегія як комплекс рішень } \\
\hline $\begin{array}{l}\text { Дойль П. С. } \\
{[4, \text { с. } 36] .}\end{array}$ & $\begin{array}{l}\text { «Стратегія - це комплекс прийнятих менеджментом рішень щодо розміщення ресурсів } \\
\text { підприємства і досягнення довгострокових конкурентних переваг на цільових ринках» }\end{array}$ \\
\hline $\begin{array}{l}\text { Колпаков В. } \\
{[8, \text { с. } 42] .}\end{array}$ & $\begin{array}{l}\text { «Стратегія - це функціональний засіб організації діяльності людей і розподілу ресурсів } \\
\text { для досягти стратегічної мети» }\end{array}$ \\
\hline
\end{tabular}

* Складено автором за матеріалами [1, 4, 6-8,, 12, 14, 16]

Фахівець у сфері крос-культурного менеджменту $\mathrm{H}$. Тодорова наголошує, що «культура не $\epsilon$ однією 3 ідей, які охоче використовують менеджери чи службовці для пояснення організаційної поведінки. Поки вони не зітнуться 3 ідеєю культури, вони часто не в змозі розглядати їі як можливе пояснення змін у функціонуванні організацій, тому приписують моделі й зміни в поведінці будь-яким іншим впливам, крім культури [14, с. 155]. Особливу роль у крос-культурному менеджменті, продовжує Н.Тодорова, відіграють переваги різноманіття. Так, культурно синергітичні переваги проявляються: у кращому розумінні іноземних службовців; дозволяють більш ефективно працювати з конкретними іноземними клієнтами; краще розуміти політичне, соціальне, юридичне, економічне, культурне середовище інших країн) [там, же, 143 с.156].

Отже більшість учених і практиків, які займаються організаційними проблемами, сьогодні усвідомили, що культура впливає на виробничі показники діяльності підприємства. Більше того, окрім впливу на організаційному рівні, добре простежується i вплив культури на окремих людей, тобто персоналу багатонаціональних компаній. Очевидним $\epsilon$, що в процесі реалізації стратегії розвитку міжнародних компаній, повстає проблема узгодження цінностей, норм поведінки; розв' язання конфліктів; налагодження комунікацій, знаходженням способів соціальної згуртованості співробітників, встановленням певного типу відносин між членами організації. Саме крос-культурний менеджмент об'єднує зусилля керівників та підлеглих на головних стратегічних напрямках розвитку міжнародної компанії, що забезпечує узгодження різноманітності.

Крос-культурний менеджмент допомагає вибудовувати комунікацію з бізнес-партнером 3 іншої культури, сформувати позитивний імідж міжнародної компанії загалом. Крос-культурний менеджмент створює основу для професійної мобільності, збільшує можливості професійної самореалізації на основі комунікативності i толерантності, що дає їм змогу успішно керувати бізнесом в умовах різних ділових культур, правильно вибудовуючи міжкультурну взаємодію, визначати причини конфліктів та запобігати їм у цілях підвищення ефективності організацій в умовах глобалізації економіки.

Задля визначення ролі крос-культурного менеджменту в стратегічному розвитку компаній було використано підхід Н. Мешко, О. Буланкіної (табл.2).

Н. Мешко та О. Буланкіна визначили вплив крос-культурного менеджменту на корпоративний успіх за категоріями: прибуток компанії, задоволеність клієнтів, вартість акцій компанії та імідж компанії, що підтвердило позитивну тенденцію успіху компанії при впровадженні крос-культурного менеджменту. 
Таблиця 2

Переваги крос-культурного менеджменту*

\begin{tabular}{|c|c|c|}
\hline № & Оцінка впливу факторів & Кластери в управлінні \\
\hline 1 & $\begin{array}{l}\text { Міжнародні ринки легше завойовуються робітниками, що є етнічними мешканцями } \\
\text { цих країн }\end{array}$ & \\
\hline 2 & $\begin{array}{l}\text { Політика міжнаціонального найму персоналу позиціонує компанію як глобального } \\
\text { гравця на міжнародних ринках }\end{array}$ & \multirow{5}{*}{$\begin{array}{c}\text { Співробітництво та } \\
\text { успіх на міжнародних } \\
\text { ринках }\end{array}$} \\
\hline 3 & Міжкультурна компетенція на основі взаємодії культурного розмаїття & \\
\hline 4 & $\begin{array}{l}\text { Культурна різноманітність забезпечує розвиток персоналу за рахунок досвіду та } \\
\text { творчого вирішення проблем }\end{array}$ & \\
\hline 5 & Міжнародні проектні групи є більш ефективними у вирішенні міжнародних завдань & \\
\hline 6 & Впровадження нових моделей мислення і поведінки & \\
\hline & Конфлікти, викликані культурними відмінностями, скорочуються & \multirow{2}{*}{$\begin{array}{c}\text { Управління } \\
\text { конфліктами }\end{array}$} \\
\hline 9 & Підвищення рівня задоволеності співробітників & \\
\hline
\end{tabular}

* Розроблено автором за матеріалами [9]

Саме тому міжнародні компанії, мають реалізувати розвиток крос-культурно менеджменту 3 урахуванням національних цінностей. Глобалізація та міжнародний поділ праці змушують шукати напрями співробітництва та взаємоповаги на засадах різноманіття. На результати впровадження кроскультурного менеджменту в стратегію розвитку міжнародної компанії суттєво впливає різноманіття. Керівництву особливо важливо приділити увагу проблемам різноманітності, коли організація реалізує стратегію розвитку. Різноманіття - це перевага в переорієнтації організації, що починає новий проект, що створює новий напрям діяльності чи оцінює тенденції з нової точки зору. Отже, культурну різноманітність треба використовувати як ресурс переваг міжнародної компанії га глобальних ринках.

Сучасні керівники все частіше розглядають крос-культурний менеджмент як потужний стратегічний чинник, що дозволяє орієнтувати всі підрозділи i окремих працівників на досягнення головної мети, що дає можливість мобілізувати ініціативу працівників, підвищувати їх особисту мотивацію. Кроскультурний менеджмент дозволяє концентрувати зусилля на головних стратегічних напрямках розвитку підприємства, що забезпечує найвищу продуктивність, успішність і прихильність ії працівників.

Отже розвиток культури пов'язаний 3 визначенням базових цінностей, знаходженням способів соціальної згуртованості співробітників, встановленням певного типу відносин між членами організації, а також із зовнішнім середовищем. В сучасних умовах, успіх компанії на глобальних ринках обумовлює: правильно побудовані професійні комунікації із закордонним партнером по бізнесу; знання особливості та законів ведення бізнесу в партнерській країні; знання особливості місцевої культури.

Здатність добровільно брати на себе i розділяти моральну відповідальність не тільки сприятиме усуненню міжкультурних розбіжностей, але й формуватиме творчу обстановку взаємної поваги, необхідності зберігати поліфонічне різноманіття світових культур.

Однак на сьогодні в Україні мало компаній, які мають спеціальні служби, що займаються формуванням і впровадженням корпоративних цінностей, тому керівництву українських підприємств ще необхідно усвідомити значимість крос-культурного менеджменту Актуальним для Одеської багатонаціональної області $\epsilon$ питання щодо значущості кроскультурного менеджменту в процесі реалізації стратегії розвитку міжнародних компаній.

Таблиця 3

Оцінка керівниками провідних міжнародних компаній Одеського регіону значущості крос-культурного менеджменту в процесі стратегії розвитку*

\begin{tabular}{|c|l|c|}
\hline $\begin{array}{c}\text { № } \\
\text { 3.П. }\end{array}$ & \multicolumn{1}{|c|}{$\begin{array}{c}\text { Оцінка значущості крос- } \\
\text { культурного менеджменту }\end{array}$} & $\begin{array}{c}\text { Питома } \\
\text { вага, \% }\end{array}$ \\
\hline 1. & $\begin{array}{l}\text { Крос-культурний менеджмент } \\
\text { повинен бути на підприємстві }\end{array}$ & 40,2 \\
\hline 2. & $\begin{array}{l}\text { Намагаються сформувати крос- } \\
\text { культурний менеджмент за } \\
\text { допомогою західних технологій }\end{array}$ & 34,4 \\
\hline 3. & $\begin{array}{l}\text { Відзначають необхідність крос- } \\
\text { культурного менеджменту на } \\
\text { підприємстві, але задля послідовної } \\
\text { роботи щодо його формування та } \\
\text { розвитку не вистачає фахівців }\end{array}$ & 20,7 \\
\hline 4. & $\begin{array}{l}\text { Наявність крос-культурного } \\
\text { менеджменту на підприємстві }\end{array}$ \\
\hline
\end{tabular}

*Розроблено автором 
Результати соціологічного обстеження 12 провідних міжнародних компаній Одеського регіону за участю автора свідчать, що їхні керівники (власники) вже набули певного досвіду у просуванні крос-культурного менеджменту (табл.3).

За даними проведеного дослідження можна зробити висновок, що практично усіма керівниками усвідомлюється важливість і необхідність використання крос-культурного менеджменту в процесі реалізації стратегії розвитку.

\section{Висновки та перспективи} досліджень. Викладене вище сформувати наступні висновки:

1. Сучасні виклики глобальному бізнесу спонукають керівників до визначення ролі кроскультурного менеджменту в процесі розробки стратегії розвитку міжнародних компаній. Проблема крос-культурного менеджменту в процесі реалізації стратегії розвитку потребує поглибленого системного вивчення 3 позицій співвідношення указаних понять та їхнього місця у системі стратегічного управління, що має стати підгрунтям більш чіткого усвідомлення низки дій у довгостроковій перспективі щодо суттєвого підвищення ефективності організаційної діяльності міжнародної компанії в умовах невизначеності i швидких змін зовнішнього середовища.
2. Головними завданнями керівників повинно стати оволодіння механізмом управління трудовою (індивідуальною, психофізіологічною тощо) діяльністю людини у суворій відповідності принципам ефективного використання ii особистісного потенціалу i формування особистості, яка володіє колективною психологією, високою кваліфікацією, розвиненим почуттям співвласника організації та високою відповідальністю, головним методом (інструментом) реалізації такої системи $\epsilon$ саме кроскультурний менеджмент, який одночасно має виступати і як одна 3 найважливіших складових усієї системи стратегічного управління підприємством.

3. Оскільки на результати впровадження кроскультурного менеджменту суттєво впливає протиріччя між історично сформованими корпоративними цінностями компаній та процесами асиміляції нових культур під впливом глобальної економічної інтеграції та міжнародної міграції фахівців, культурну розмаїтість треба використовувати як ресурс переваг міжнародної компанії.

В контексті провадження крос-культурного менеджменту подальші дослідження у цьому напрямку потребують подальшого дослідження механізму подолання опору змінам при реалізації стратегії розвитку міжнародних компаній.

\section{ПЕРЕЛІК ВИКОРИСТАНИХ ДЖЕРЕЛ}

1. Азоев А.Г. Конкуренция: анализ, стратегия и практика. Монография. / А.Г. Азоев. - М.: Центр экономики и маркетинга, 1996. - 208 с.

2. Балабанова Л. В. Управління персоналом. / Л. В. Балабанова, О. В.Сардак.- К.: Центр учбової літератури, 2011. - $468 \mathrm{c}$.

3. Бурак О.С. Крос-культурна комунікація як наслідок глобалізаційних крос-культурних контактів // [Електронний ресурс]. - Режим доступу: http://www.nbuv.gov.ua/old_jrn/Soc_Gum/Grani/2012_5/27.pdf

4. Дойль П. Маркетинг, менеджмент и стратегии / П. Дойль, Ф. Штерн. - СПб.: Питер, 2007. - 544c.

5. Жихарева В.В. Савельєва Т.М. Формування стратегії розвитку підприємства в умовах невизначеності / В. В. Жихарева, Т.М. Савельєва // Економіка і суспільство. - Випуск № 9. - 2017.

6. Иванов Ю.Н. Экономическая статистика / под ред.. проф. Ю. Н. Иванова. - 3-е изд., перераб. и доп. - М.: «Инфра - М», 2009. - 736 с.

7. Карлоф Б. Деловая стратегия / Б. Карлоф. - М.: Экономика, 1991. - 210с.

8. Колпаков В. Концептуальные основы стратегии управления / В. Колпаков // Персонал. - 2002. - № 3. C. $38-44$.

9. Мешко Н., Буланкіна О. Культурний менеджмент у корпоративних стратегіях міжнародних компаній. // [Електронний ресурс]. - Режим доступу: http://www.economy.nayka.com.ua/?op=1\&z=1274KPOC-H.

10. Папка Р.В. Розробка та реалізація стратегії розвитку підприємства в управлінні зовнішньоторговельними операціями. // [Електронний ресурс]. - Режим доступу: http://www.rusnauka.com/29_PMN_2015/Economics/ 2_199266.doc.htm

11. Питерс Т.В. В поисках эффективного управления (опыт лучших компаний) Т. Питерс, Р. Уотерман: пер. с англ. - М.: Прогресс, 1986. - 423 с.

12. Петрушенко Ю.М. Крос-культурні аспекти підвищення ефективності міжнародного бізнесу / Ю.М. Петрушенко // Вісник Хмельницького національного університету. - 2009. - № 5. - Т.1. // [Електронний pecypc]. - Режим доступу: http://journals.khnu.km.ua/vestnik/pdf/ekon/2009_5_1/pdf/146-148.pdf

13. Романуха О. Роль крос-культурних комунікацій у менеджменті організацій / О. Романуха// Економіка i суспільство.- 2017. - Вип.№ 9. - С. 608-613. URL: http://www.economyandsociety.in.ua/journal/9_ukr/103.pdf

14. Тодорова Н. Крос-культурний менеджмент / Н. Тодорова. - Донецьк: ДонНТУ, 2008. - 330с. 
15. Щетініна В., Рудакова С., Кравець С. Сутність крос-культурної компетентності: від теорії до практики / В. Щетініна, С. Рудакова, С. Кравець // [Електронний ресурс]. - Режим доступу: at http:www.nbuv.gov.ua/old_jrn/Soc_Gum/Ei/2012_50/Buten.pdf.

16. Chandler A. D. Strategy and Structure: Chapters in the History of the American Industrial Enterprise/ A. D. Chandler. - The MIT Press, 1969. - 464c.

17. Huntington S. The Clash of Civilizations and Remaking of World Order / S. Huntington. - New York: Simon and Schuster, 1996.

\section{REFERENCES}

1. Azoev, A.G. (1996) Konkurentsiya: analiz, strategiya i praktika. Monografiya [Competition: Analysis, Strategy and Practice]. - M.: Tsentr ekonomiki i marketinga [In Russian].

2. Balabanova, L. V. \& Sardak, O. V. (2011) Upravlinnya personalom [Human resources management]. - K.: Tsentr uchbovoyi literatury [In Ukrainian].

3. Burak, O. S. (2012) Kros-kul'turna komunikatsiya yak naslidok hlobalizatsiynykh kros-kul'turnykh kontaktiv [Cross-cultural communication as a result of globalized cross-cultural contacts]. Retrieved from: http://www.nbuv.gov.ua/old_jrn/Soc_Gum/Grani/2012_5/27.pdf [In Ukrainian].

4. Doyl', P. (2007) Marketing, menedzhment i strategii [Marketing, management and strategy]. - SPb.: Piter [In Russian].

5. Zhikhareva, V.V. \& Savelyeva, T.M. (2017) Formuvannia stratehii rozvytku pidpryiemstva v umovakh nevyznachenosti [Formation of an enterprise development strategy under conditions of uncertainty]. Ekonomika $\mathrm{i}$ suspilstvo -Economy and Society, 9 [In Ukrainian].

6. Ivanov, Yu. N. (2009) Ekonomicheskaya statistika [Economic statistics]- - M.: «Infra - M» [In Russian].

7. Karlof, B. (1991) Delovaya strategiya [Business strategy]. - M.: Ekonomika [In Russian].

8. Kolpakov, V. (2002) Kontseptualnyye osnovy strategii upravleniya [Conceptual basis of the management strategy]. Personal - Personnel, 3, 38-44 [In Russian].

9. Meshko, N. \& Bulankina, O. (n.d.) Kul'turnyy menedzhment u korporatyvnykh stratehiyakh mizhnarodnykh kompaniy [Cultural management in corporate strategies of the international companies]. Retrieved from: http://www.economy.nayka.com.ua/?op=1\&z=1274KPOC-H [In Russian].

10.Papka, R.V. (2015) Rozrobka ta realizatsiya stratehiyi rozvytku pidpryyemstva v upravlinni zovnishn'otorhovel'nymy operatsiyamy [Development and implementation of an enterprise development strategy in foreign trade operations management]. Retrieved from: http://www.rusnauka.com/29_PMN_2015/ Economics/2_199266.doc.htm [In Ukrainian].

11.Piters, T.V. (1986) V poiskakh effektivnogo upravleniya (opyt luchshikh kompaniy) [In search of effective management (experience of the best companies)]. - M.: Progress [In Russian].

12.Petrushenko, Yu. (2009) Kros-kul'turni aspekty pidvyshchennya efektyvnosti mizhnarodnoho biznesu [Crosscultural aspects of increasing the international business efficiency]. Visnyk Khmel'nyts'koho natsional'noho universytetu - Herald of Khmelnitsky National University, 5. Retrieved from: http://journals.khnu.km.ua/vestnik/pdf/ekon/2009_5_1/pdf/146-148.pdf [In Ukrainian].

13.Romanukha, O. (2017) Rol' kros-kul'turnykh komunikatsiy u menedzhmenti orhanizatsiy [The role of crosscultural communications in organizations' management]. Ekonomika i suspil'stvo - Economics and Society, 9, 608613. Retrieved from: http://www.economyandsociety.in.ua/journal/9_ukr/ 103.pdf [In Ukrainian].

14.Todorova, N. (2008) Kros-kul'turnyy menedzhment [Cross-cultural management]. - Donets'k: DonNTU [In Russian].

15. Shchetinina, V. \& Rudakova, S. \& Kravets, S. (2017) Sutnist kros-kulturnoi kompetentnosti: vid teorii do praktyky [The essence of cross-cultural competence: from theory to practice]. Retrieved from: http:www.nbuv.gov.ua/old_jrn/Soc_Gum/Ei/2012_50/Buten.pdf

16.Chandler, A.D. (1969) Strategy and Structure: Chapters in the History of the American Industrial Enterprise. The MIT Press [In English].

17.Huntington, S. (1996) The Clash of Civilizations and Remaking of World Order. - New York: Simon and Schuster [In English].

Одержано 15.03. 2018 р. 